facilitating access to health care. The difficulties with legal recognition of rights to health care are explored by Dieter Giesen. Some of the themes considered by Professor Giesen, notably the duty to rescue, are also taken up in Barry Furrow's essay examining provision of care to persons falling outside the health insurance scheme in the USA. Lawrence Gostin in his essay "The Americans with Disabilities Act and the corpus of anti-discrimination law: a force for change in the future of public health legislation", discusses the extent to which public health powers in the USA conflict with the rights of persons with communicable diseases and the role which can be played by anti-discrimination legislation in the form of the Americans with Disabilities Act. Deficiencies in health provision and sensitivity to the particular needs of ethnic groups in England are considered by David Pearl. This essay also illustrates the existing difficulties in attempting to use English law as a means of obtaining access to health care resources.

The remaining essays provide: an examination of dimensions of justice in the context of the operation of the Canadian Health system, by Carolyn Tuhoy; the use of financial incentives in a market in organs, by James Blumstein, and problems of access to health care experienced by those from the USA AfricanAmerican community, by Vernellia E Randall.

All the essays in the collection explore the central theme in the context of a well-developed Western health care system. It perhaps should be borne in mind that a comparative analysis of matters regarding justice and health care in relation to, for example, the Third World, would of course, bring into focus somewhat different issues. While some essays draw cross-jurisdictional comparisons the primary focus of this collection is American, with five out of nine of the essays concentrating upon American health care. The collection is thus perhaps not truly "comparative". Nevertheless, overall fustice and Health Care: Comparative Perspectives provides a number of lively, provocative and scholarly contributions to what is becoming an increasingly vociferous debate.

J V McHALE Lecturer in Law, Faculty of Law, University of Manchester

\title{
Torture: Human Rights, Medical Ethics and the Case of Israel
}

\author{
Edited by Neve Gordon and \\ Ruchama Marton, London, Z.ed \\ Books, 1995, 206 pages, $£ 42.50$ hc, \\ $£ 16.95$ sc.
}

The book derives from a conference on the International Struggle against Torture and the Case of Israel, held in Tel-Aviv in 1993, organised by the Association of Israeli-Palestinian Physicians for Human Rights and the Public Committee against Torture in Israel. It is not merely a proceedings, but a compilation by seventeen of the participants with diverse interests and skills, though it does include reports of workshops held at the end of each section of the conference.

Considering the composition of the population of Israel and the past personal experiences of many of its citizens, it might be thought that the very idea of torture would be anathema. However, it is a tragic fact that the whole history of IsraeliPalestinian relationships has been tainted by allegations of inhuman treatment on both sides, but particularly by Israeli soldiers and interrogators.

The book is divided into four parts. The first, dealing with the public realm takes the political status first, describing how harsh treatment amounting to torture has not been condemned but made legitimate by the Landau Report. In 1987 a commission of inquiry headed by Chief Justice Moshe Landau, was set up to investigate complaints of ill-treatment of Palestinian detainees. The commission, instead of outlawing torture, authorised the General Security Service (GSS) to use "a moderate measure of physical force" in the interrogation of "security" detainees. The recommendations became law. Though the exact methods permitted have never been published, the interpretation of "moderate physical force" has led to the use of such techniques as beating, hooding, sleep deprivation, confining in a cupboard-sized cell, electric shocks and vigorous shaking. Next, the social response to the situation is described. There are three lines of argument commonly used: i: To deny that torture takes place except as an occasional aberration; ii: Avoiding the use of pejorative words and substituting phrases such as "moderate physical pressure" or what the French in
Algiers called "special procedures"; and iii: Acknowledging its use but justifying it by claiming that harsh measures are necessary to bring the emergency to a more speedy conclusion. Even "liberal" sections of the community are guilty of these deceptions, colluding with the majority in turning a blind eye.

The second section deals with the involvement of health professionals in torture. It is alleged that a doctor is in the background behind every torturer/ interrogator. He performs a pretorture examination, monitors the torture process, examines and takes care of the prisoner following the infliction of torture and writes a medical opinion or a pathology report. A form of "Fitness for torture" used by the Department of Interrogation asks the doctor to certify whether there are any medical reasons for limitations to a stay in an isolated cell, chaining, hooding or prolonged standing. When the Israeli-Palestinian Physicians for Human Rights protested to the Israeli Medical Association (IMA) about this form, their chairperson, Dr Miriam Tzangen, wrote urgently to the Prime Minister. He replied that it was simply experimental and its use would be discontinued. Apart from this example, the IMA has remained silent over the mounting evidence of participation by doctors in interrogation by the security services, in spite of the fact that the terms of the Declaration of Tokyo (to which the IMA is a signatory) are clearly being breached. They even failed to take any action when one of their colleagues, a Palestinian doctor, was detained and ill-treated.

The workshop at the end of this section of the conference decided on a number of measures which could be expected to improve the record of the health professionals coming into contact with evidence of torture. These included better education in ethics for students and doctors, mechanisms of reporting offences anonymously, and making video records of interrogations.

The third brief section, which deals with the legal struggle against torture, begins with a history of torture in Israel, giving examples of confessions being extracted from Palestinian detainees by torture as early in the Occupation as 1968, when the very existence of the Shabak, the interrogation organisation, was officially denied though it enjoyed a symbiotic relationship with the police, judiciary and elements of the medical profes- 
sion. In spite of prolonged complaints over the years, defence lawyers have not been able to obtain recognition from the military courts that their clients have been tortured and sometimes killed by their interrogators, while members of Shabak have often been acquitted of violations. There is a valuable description of the role of the autopsy in cases of death in custody in different countries around the world, whether by the "black box" method, under which the pathologist has access only to the physical evidence displayed by the body, or the "gestalt" method, whereby the pathologist has all relevant material before him or her and has an opportunity to determine the circumstances as well as the immediate cause of death. In Israel, the former method is in use, so that the autopsy is isolated from the scene and circumstantial aspects of the case, thus allowing courts to ignore or refute damaging evidence.

It is an astonishing fact that the GSS, which is able to request the police to arrest a suspect and then take him for prolonged interrogation and which has independent interrogation wings in prisons, and whose sealed evidence can persuade a judge to extend a prisoner's detention, has no status in law. Indeed its very existence was denied until the Landau Commission gave it legitimacy in 1985. Before that time Israel was a "denying" state. Now it is an "inquisition" state.

The final section of the book deals with the rehabilitation of torture victims: firstly identification and recognition is covered, then comes a survey of the experience of Palestinians in Israeli prisons; the role of compensation in rehabilitation follows, and finally, there is a description of the founding and ethos of the Medical Foundation for the Care of Victims of Torture in London.

Useful appendices list the international declarations against torture and for the protection of prisoners, as well as codes of medical and nursing ethics.

This is a very disturbing book which presents its evidence persuasively. Since it was published, events have moved forward - the Occupied Territories are being returned to Palestinian rule so there should be fewer detainees subject to interrogation and torture, but a new "Prohibition of Torture" Bill, at present before the Israeli Knesset, appears designed to relax rather than strengthen controls on interrogation of detainees.

DUNCAN FORREST

Medical Foundation for the Care of Victims of Torture, 96-98 Grafton Street, London NW5 $3 E \mathcal{F}$

\section{The Ethics of Animal and Human Experimentation}

Edited by Peter P De Deyn, London, John Libbey and Co, 1994, 369 pages, £40, \$US74.

A good deal of experimentation in medicine is conducted upon animals and humans, and a good many ethical issues arise in the course of such research. The present volume discusses a number of these issues. The authors are mostly drawn from Belgium and the Netherlands and come from a number of different disciplines, though clinical and laboratory scientists predominate. I think Anglo-American medical ethicists will be interested to see the fruits of Belgian and Dutch thinking on many of the very topics that engage them. Certainly, no one could come away from this volume unimpressed by the collective attempt to show that ethically sensitive biomedical research of high quality is possible.

The book opens with sections on ethics and medicine and on legislation on animal/human experimentation in Belgium and the Netherlands. The latter section is quite interesting, and the papers by Nys and van Wijman give the reader at least an elementary working knowledge of the state of play in those two countries. The former section is rather disappointing: the papers provide no extended discussion of specific ethical frameworks within which questions about the justification of our research practices with animals and humans can be pursued; neither do they go into the important differences that characterise competing ethical frameworks - frameworks which many of us are often forced to choose between.

The book then proceeds with successive sections on animal research, on randomised clinical trials, and on medical research on humans of special interest, such as children, psychiatric patients, and those with AIDS. These three sections form the substance of the book, and the last section, particularly in light of the papers by Cosyns on psychiatric patients as research $\overline{\bar{\gamma}}$ subjects, Clara on research involving children, and Annas on research on patients with AIDS and cancer, is quite successful in bringing out how our ethical thinking has to take account of the special circumstances of different research subjects. The section on randomised clinical trials is too diffuse to come to a specific point, but the papers by Dillmann on $\overrightarrow{0}$ Alzheimer's disease, Kimsma on some of the tussles to do with informed con- $\omega$ sent, and Noach on ethics in drug development are quite interesting. As for the section to do with animal iv research, it rather predictably comes to the conclusion that our use of animals for medical purposes is justi- of fied, and, apart from a paper by 0 Morrison on animal rights movements in the United States, there is little by way of opposition put in the way of reaching this conclusion.

While the essays do succeed in raising all manner of issues of ethical $\overrightarrow{0}$ import with regard to research o animals and humans, the book strik me as flawed at a deeper level. The central problem is not that there insufficient discussion of ethica्al frameworks within which to locate

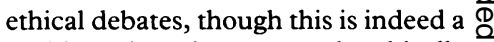
problem, but that so much ethically $\overrightarrow{\vec{B}}$ is taken for granted, based upon currently accepted medical research practice, that deep challenges to many of these assumptions go unexplored. The result is a volume with which readers feel comfortable and so $\overparen{D}$ reassured, morally: to be sure, there $\frac{0}{3}$ are ethical issues to which we need to be more sensitive than we presently 0 are, ethical issues that we need to work further and more carefully upon, 윽 but by and large high quality medical research can be done within established ethical guidelines.

Things are too easy. For example, $N$ one of the assumptions that underlies $N$ most of the essays in this book is that benefit to humans can justify all $\omega$ manner of things in medical research, without any clear statement of why weco should think this or how exactly $\frac{}{D}$ arguments from benefit are supposed $\stackrel{\infty}{?}$ to run. Thus, in the animal research $\square$ section, human benefit is assumed to $\bar{O}$ justify animal research. How and in $\overrightarrow{\mathbb{D}}$ virtue of what is it supposed to do $\frac{O}{\mathbb{D}}$ this? And if it can justify using animals $\varrho$ to certain ends, why can it not justify using unfortunate humans to the same ends? Why does informed consent 